\title{
Activity of the dietary flavonoid, apigenin, against multidrug-resistant tumor cells as determined by pharmacogenomics and molecular docking
}

\author{
Mohamed Saeed ${ }^{1 *}$, Thomas Efferth, Onat Kadioglu', Hassan Khalid², Yoshikazu Sugimoto ${ }^{3}$
}

From Breast Cancer Immunotherapy Symposium (BRECIS), part of the Sidra Symposia Series, held in partnership with the Society for Immunotherapy of Cancer

Doha, Qatar. 13-14 April 2015

Natural products have been extensively studied and involved in cancer therapy field [1], apigenin has considerable cytotoxic activity in vitro and in vivo. Despite many mechanistic studies, less is known about resistance factors hampering apigenin's activity. We investigated the ATP-binding cassette $(\mathrm{ABC})$ transporters $B C R P / A B C G 2$, P-glycoprotein/ABCB1 and its close relative ABCB5. Apigenin inhibited not only P-glycoprotein, but also BCRP by increasing cellular uptake of doxorubicin and showed synergistic inhibitory effect in combination with doxorubicin or docetaxel against multidrugresistant cells. To perform in silico studies, we first generated homology models for human P-glycoprotein and ABCB5 based on the crystal structure of murine P-glycoprotein. Their nucleotide binding domains (NBDs) revealed the highest degrees of sequence homologies (89\%-100\%), indicating that ATP binding and cleavage is of crucial importance for $\mathrm{ABC}$ transporters. In silico studies showed a pigenin bound to the NBDs of P-glycoprotein and ABCB5. Hence, apigenin may compete with ATP for NBD-binding leading to energy depletion to fuel the transport of $A B C$ transporter substrates. Furthermore, we performed COMPARE and hierarchical cluster analyses of transcriptome-wide mRNA expression profiles of the National Cancer Institute tumor cell line panel. Microarray-based mRNA expressions of genes of diverse biological functions significantly predicted responsiveness of tumor cells to apigenin [2].

\section{Authors' details}

'Department of Pharmaceutical Biology, Institute of Pharmacy and Biochemistry - Johannes Gutenberg-University, Mainz, Germany. ${ }^{2}$ Department of Pharmacognosy, University of Khartoum, Khartoum, Sudan. ${ }^{3}$ Division of Chemotherapy, Faculty of Pharmacy - Keio University, Tokyo, Japan.

\section{Published: 14 August 2015}

\section{References}

1. Newman DJ, Cragg GM: Natural products as sources of new drugs over the 30 years from 1981 to 2010. J Nat Prod. 2012, 75(3):311-35.

2. Saeed M, Kadioglu O, Khalid H, Sugimoto Y, Efferth T: Activity of the dietary flavonoid, apigenin, against multidrug-resistant tumor cells as determined by pharmacogenomics and molecular docking. J Nutr Biochem 2015, 26(1):44-56.

\section{doi:10.1186/2051-1426-3-S1-P10}

Cite this article as: Saeed et al:: Activity of the dietary flavonoid, apigenin, against multidrug-resistant tumor cells as determined by pharmacogenomics and molecular docking. Journal for ImmunoTherapy of Cancer 2015 3(Suppl 1):P10.

Submit your next manuscript to BioMed Central and take full advantage of:

- Convenient online submission

- Thorough peer review

- No space constraints or color figure charges

- Immediate publication on acceptance

- Inclusion in PubMed, CAS, Scopus and Google Scholar

- Research which is freely available for redistribution 